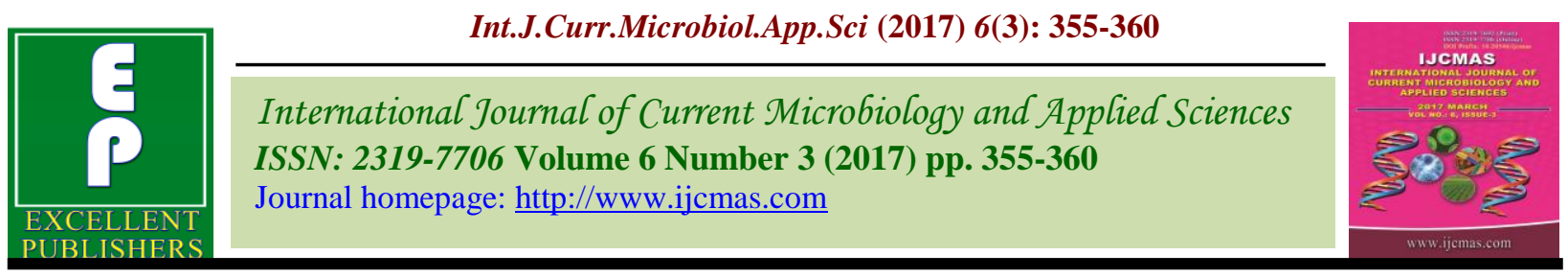

Original Research Article

https://doi.org/10.20546/ijcmas.2017.603.040

\title{
Evaluation of Germplasmfor PCV, GCV and Heritability in Luffa (Luffa cylindrica Roem.)
}

\section{Praveen Kumar Singh ${ }^{1}$, V.B. Singh ${ }^{1}$, Chandan Kumar Singh², Manoj Kumar ${ }^{3 *}$, Vimlesh Kumar ${ }^{1}$ and Nitish Kumar ${ }^{4}$}

\author{
${ }^{1}$ Department of Vegetable Science, NDUAT Kumarganj Faizabad-224229, India \\ ${ }^{2}$ Department of Plant Pathology, NDUAT Kumarganj Faizabad-224229, India \\ ${ }^{3}$ Extension Education, NDUAT Kumarganj Faizabad-224229, India \\ ${ }^{4}$ Agriculture Meteorology, NDUAT Kumarganj Faizabad-224229, India \\ *Corresponding author
}

A B S T R A C T

Keywords

Luffa (Luffa cylindrical Roem.), Germplasm, GCV, PCV, Heritability.

Article Info

Accepted:

10 February 2017

Available Online:

10 March 2017
The present investigation was carried out at Main Experiment Station, Department of Vegetable Science, Narendra Deva University of Agriculture \& Technology, Kumarganj, Faizabad (U.P.) during summer season, to evaluate the available germplasms for yield and its component traits of 45 genotypes, with three replications in Randomized Block Design. The study revealed that the mean sum squares due to genotypes were significant for all the characters, though the wide range of genetic variability in the material. The higher magnitude of coefficient of variation at phenotypic as well as genotypic levels were observed days to anthesis first staminate flower, days to anthesis first pistillatte flower and vine length and lower value in days taken for anthesis of first staminate flower and days to first fruit harvest. The presences of high heritability with high genetic advance in per cent of mean were observed for node number to first staminate floweranthesis and vine length at last harvest during both the years exhibiting additive gene effect.

\section{Introduction}

Luffa (Luffa cylindrica Roem.) commonly called as sponge gourd, loofah vegetable sponge or dish cloth, having diploid chromosome number $2 \mathrm{n}=2 \mathrm{x}=26$. The sponge gourd large amount of variation has been observed for many economically important traits. In India, wide range of variability is available in the land races or cultivars, in terms of qualitative as well as quantitative characters of sponge gourd. The fruit number and weight, uniform thickness, cylindrical fruit free from bitterness, high female: male sex ratio, earliness, non fibrous fruit at edible stage and resistance to powdery and downy mildew. Variability in cucurbitaceous crop occurs in the form of land races, traditional cultivars, wild relatives form and related non edible wild weedy species. In India little attention has been given for the genetic improvement of sponge gourd by collecting diverse germplasm, their morphological characterization and assessing the variability parameters like coefficient of variation. The appropriate breeding methodologies may be adopted for genetic improvement of this crop for simultaneously 
improvement of different characters, information regarding mutual relationship among the characters and direction of correlation analysis provides an effective means of finding out direct and indirect causes of association among causal variables. Though the literature in respect of germplasm evaluation variability and correlation studies in sponge gourd is not meager but these are based on testing of limited number of germplasm. Moreover, the results of the earlier studies on such aspects are relevant only for the materials and environments involved in the particular study and cannot be generalized. Therefore, studies on above aspects on the available germplasm under the environment where, it is to be exploited, is essential for successful utilization of germplasm resources in the development of superior varieties.

\section{Materials and Methods}

The experimental material for the present investigation comprised 30 genotypes of sponge gourd selected on the basis of genetic variability from the germplasm stock maintained at Main Experiment Station in the Department of Vegetable Science, N.D. University of Agriculture and Technology, Narendra Nagar (Kumarganj), Faizabad (U.P.) during the summer season. The experiment was conducted in Randomized Complete Block Design with three replications to assess the performance of 30 genotypes of sponge gourd. The crop was planted in $3.0 \mathrm{~m}$. for row length, spaced 3.0 $\mathrm{m}$. apart where, $0.5 \mathrm{~m}$. Plant to plant spacing was maintained. The experiment was conducted during summer season of 2014 and 2015. All the recommended agronomic package and practices and plant protection measures were followed to raise a good crop. The observations were recorded on the five plants, summed up and divided by five to get mean value. The characters observed viz., node no to first staminate flower anthesis, node no to pistillate flower anthesis, days taken for anthesis of first staminate flower, days taken for anthesis of first pistillate flower, days to first marketable fruit harvest, fruit length $(\mathrm{cm})$, fruit diameter $(\mathrm{cm})$ average fruit weight $(\mathrm{g})$, no. of fruits per plant, marketable fruit yield per plant $(\mathrm{kg})$ and vine length at last harvest (m).

\section{Statistical analysis}

The average values for each genotype in each replication for the traits studied were used for further statistical analysis. A brief outline of the procedure adopted for the estimation of statistical parameters. Analysis of variance, the data for the component traits was analysed as per the following model given by Panse and Sukhatme (1984). The calculated ' $F$ ' values were compared with the tabulated ' $\mathrm{F}$ ' values at $5 \%$ level of significance. If the calculated ' $F$ ' value was higher than the tabulated, it was considered to be significant. All the characters which showed significant differences among genotypes were further subjected to the analysis for the different parameters. The phenotypic, genotypic, environmental coefficients of variation, heritability in broad sense $\left(\mathrm{h}^{2}\right.$ bs $)$ and the expected genetic advance (GA) for different characters content were calculated as suggested by Burton and De Vane (1953) and Johnson et al., (1955).

\section{Results and Discussion}

The result (Table 1) obtained in the present investigation indicated that the genotypes evaluated differed significantly for all the fourteen traits. Thus, suggested existence wide range of variability in the germplasm studied. The phenotypic variance of each character was partitioned into genotypic and environmental comfier in order components. The phenotypic and genotypic coefficient of 
variations were estimated to assess the existing variability are present in table 2 . In general the phenotypic coefficient of variability was higher than genotypic coefficient of variability which indicated that environment influenced considerably in expression of these traits. The higher magnitude of coefficient of variation at phenotypic as well as genotypic levels were observed for node number to first staminate flower anthesis and vine length at last harvest during both the years and node number to first pistillate flower anthesis in case of $\mathrm{Y}_{2}$ moderate value for number of nodes per vine at last harvest, number of primary branches per vine at last harvest, fruit length of marketable fruits, average fruit weight marketable fruit yield per plant during both the years while only phenotypic coefficient of variation moderate value were observed in days to anthesis of first staminate flower and inter nodal length whereas the rest of the characters showed lower value of phenotypic as well as genotypic coefficient of variability result obtained in present investigations are in agreement with the finding of Mohanty (2000) in sponge gourd and Singh (2006) in bitter gourd.

Table.1 Analysis of Variance for fourteen characters in sponge gourd

\begin{tabular}{|c|c|c|c|c|c|c|c|c|c|}
\hline $\begin{array}{l}\text { Source of } \\
\text { Variation }\end{array}$ & Years & d.f. & $\begin{array}{l}\text { Node number } \\
\text { to first } \\
\text { staminate } \\
\text { floweranthesis }\end{array}$ & $\begin{array}{l}\text { Node number } \\
\text { to first } \\
\text { pistillate } \\
\text { floweranthesis }\end{array}$ & $\begin{array}{l}\text { Days } \\
\text { taken for } \\
\text { anthesis } \\
\text { of first } \\
\text { staminate } \\
\text { flower }\end{array}$ & $\begin{array}{l}\text { Days } \\
\text { taken } \\
\text { foranthesis } \\
\text { of first } \\
\text { pistillate } \\
\text { flower }\end{array}$ & $\begin{array}{l}\text { Days to } \\
\text { first } \\
\text { fruit } \\
\text { harvest }\end{array}$ & $\begin{array}{l}\text { Number } \\
\text { of Node } \\
\text { per vine } \\
\text { at last } \\
\text { harvest }\end{array}$ & $\begin{array}{l}\text { Inter } \\
\text { Nodal } \\
\text { Length } \\
\text { (cm) }\end{array}$ \\
\hline \multirow[t]{2}{*}{ Replicates } & $\mathrm{Y}_{1}$ & 2 & 0.582 & 0.567 & 0.563 & 3.478 & 2.936 & 0.276 & 0.836 \\
\hline & $\mathrm{Y}_{2}$ & 2 & 0.168 & 1.374 & 2.876 & 27.878 & 36.914 & 14.397 & 0.004 \\
\hline \multirow[t]{2}{*}{ Treatments } & $\mathrm{Y}_{1}$ & 44 & $19.505 * *$ & $23.312 * *$ & $79.058 * *$ & $67.270 * *$ & $72.615 * *$ & $289.433 * *$ & $3.471 * *$ \\
\hline & $\mathrm{Y}_{2}$ & 44 & $21.172 * *$ & $27.061 * *$ & $81.126^{* *}$ & $71.279 * *$ & $71.360 * *$ & $270.531 * *$ & $3.941 * *$ \\
\hline \multirow[t]{2}{*}{ Error } & $\mathrm{Y}_{1}$ & 88 & 0.219 & 0.552 & 8.872 & 9.307 & 23.720 & 23.062 & 0.363 \\
\hline & $\mathrm{Y}_{2}$ & 88 & 0.285 & 0.836 & 9.198 & 8.824 & 13.694 & 23.547 & 0.350 \\
\hline
\end{tabular}

\begin{tabular}{|l|l|l|l|l|l|l|l|l|l|}
\hline \multirow{2}{*}{$\begin{array}{l}\text { Source of } \\
\text { Variation }\end{array}$} & Years & d.f. & $\begin{array}{l}\text { Vine } \\
\text { length }(\mathbf{m}) \\
\text { at last } \\
\text { harvest }\end{array}$ & $\begin{array}{l}\text { Number } \\
\text { ofprimary } \\
\text { branches } \\
\text { per plant }\end{array}$ & $\begin{array}{l}\text { Fruit length } \\
(\mathbf{c m}) \text { of } \\
\text { marketable } \\
\text { fruits }\end{array}$ & $\begin{array}{l}\text { Fruit } \\
\text { diameter } \\
(\mathbf{c m})\end{array}$ & $\begin{array}{l}\text { Number } \\
\text { of fruits } \\
\text { per } \\
\text { plant }\end{array}$ & $\begin{array}{l}\text { Average } \\
\text { fruit } \\
\text { weight }(\mathbf{g})\end{array}$ & $\begin{array}{l}\text { Marketable } \\
\text { fruit yield } \\
\text { per plant } \\
(\mathbf{k g})\end{array}$ \\
\hline Replicates & $\mathrm{Y}_{1}$ & 2 & 0.078 & 0.345 & 0.827 & 0.006 & 2.800 & 330.774 & 0.176 \\
\cline { 2 - 10 } & $\mathrm{Y}_{2}$ & 2 & 0.123 & 0.003 & 0.113 & 0.009 & 4.093 & 363.284 & 0.139 \\
\hline Treatments & $\mathrm{Y}_{1}$ & 44 & $4.116^{* *}$ & $5.757^{* *}$ & $94.943^{* *}$ & $0.579^{* *}$ & $99.400^{* *}$ & $3213.739^{* *}$ & $1.724^{* *}$ \\
\cline { 2 - 10 } & $\mathrm{Y}_{2}$ & 44 & $4.267^{* *}$ & $5.869^{* *}$ & $95.200^{* *}$ & $0.313^{* *}$ & $88.648^{* *}$ & $3237.729^{* *}$ & $1.851^{* *}$ \\
\hline Error & $\mathrm{Y}_{1}$ & 88 & 0.143 & 0.298 & 6.625 & 0.064 & 4.728 & 165.555 & 0.071 \\
\cline { 2 - 10 } & $\mathrm{Y}_{2}$ & 88 & 0.143 & 0.291 & 7.648 & 0.069 & 4.350 & 153.570 & 0.065 \\
\hline
\end{tabular}


Table.2 Estimates of mean, range, coefficient of variation, heritability and genetic advance in sponge gourd over two years (2014 and 2015)

\begin{tabular}{|c|c|c|c|c|c|c|c|c|c|}
\hline \multirow[t]{3}{*}{ Characters } & \multirow[t]{3}{*}{ Years } & \multirow{2}{*}{$\begin{array}{l}\text { Grand } \\
\text { mean }\end{array}$} & \multicolumn{2}{|c|}{ Range of mean values } & \multicolumn{3}{|c|}{ Coefficient of variation } & \multirow{2}{*}{$\begin{array}{c}\text { Heritability } \\
\text { in Broad } \\
\text { sense (\%) }\end{array}$} & \multirow{2}{*}{$\begin{array}{c}\text { Genetic } \\
\text { advance in } \\
\text { per cent of } \\
\text { mean }\end{array}$} \\
\hline & & & Parents & Crosses & PCV & GCV & ECV & & \\
\hline & & 1 & 2 & 3 & 4 & 5 & 6 & 8 & 9 \\
\hline \multirow{2}{*}{$\begin{array}{c}\text { Node number to first } \\
\text { staminate floweranthesis }\end{array}$} & $\mathrm{Y}_{1}$ & 7.69 & 4.73 to 15.33 & 4.77 to 13.43 & 33.51 & 32.95 & 6.08 & 97 & 66.75 \\
\hline & $\mathrm{Y}_{2}$ & 7.81 & 4.17 to 15.53 & 4.70 to 13.10 & 34.48 & 33.80 & 6.84 & 96 & 68.25 \\
\hline \multirow{2}{*}{$\begin{array}{l}\text { Node number to first } \\
\text { pistillate floweranthesis }\end{array}$} & $\mathrm{Y}_{1}$ & 11.51 & 7.10 to 18.23 & 7.57 to 18.23 & 24.79 & 23.93 & 6.46 & 93 & 47.60 \\
\hline & $\mathrm{Y}_{2}$ & 11.59 & 7.10 to 20.43 & 7.03 to 19.23 & 26.70 & 25.51 & 7.89 & 91 & 50.21 \\
\hline \multirow{2}{*}{$\begin{array}{l}\text { Days taken foranthesis of } \\
\text { first staminate flower }\end{array}$} & $\mathrm{Y}_{1}$ & 36.23 & 28.50 to 48.47 & 27.37 to 49.80 & 15.68 & 13.35 & 8.22 & 73 & 23.42 \\
\hline & $\mathrm{Y}_{2}$ & 36.38 & 29.53 to 49.53 & 28.87 to 46.90 & 15.83 & 13.46 & 8.34 & 72 & 23.57 \\
\hline \multirow{2}{*}{$\begin{array}{l}\text { Days taken foranthesis of } \\
\text { first pistillate flower }\end{array}$} & $\mathrm{Y}_{1}$ & 39.99 & 34.37 to 50.33 & 32.47 to 48.73 & 13.38 & 10.99 & 7.63 & 67 & 18.60 \\
\hline & $\mathrm{Y}_{2}$ & 39.89 & 34.73 to 48.43 & 31.83 to 48.50 & 13.65 & 11.44 & 7.45 & 70 & 19.75 \\
\hline \multirow[t]{2}{*}{ Days to first Fruit harvest } & $\mathrm{Y}_{1}$ & 53.91 & 47.50 to 62.50 & 44.13 to 64.20 & 11.73 & 7.49 & 9.03 & 41 & 9.85 \\
\hline & $\mathrm{Y}_{2}$ & 54.30 & 46.63 to 63.53 & 45.53 to 65.00 & 10.57 & 8.07 & 6.81 & 58 & 12.71 \\
\hline \multirow{2}{*}{$\begin{array}{c}\text { Number of Nodes per Vine } \\
\text { At Last harvest }\end{array}$} & $\mathrm{Y}_{1}$ & 55.41 & 41.23 to 75.63 & 40.47 to 71.40 & 19.09 & 17.01 & 8.67 & 79 & 31.21 \\
\hline & $\mathrm{Y}_{2}$ & 55.05 & 39.37 to 72.63 & 40.40 to 70.60 & 18.69 & 16.48 & 8.81 & 78 & 29.94 \\
\hline
\end{tabular}


Int.J.Curr.Microbiol.App.Sci (2017) 6(3): 355-360

\begin{tabular}{|c|c|c|c|c|c|c|c|c|c|}
\hline & & 1 & 2 & 3 & 4 & 5 & 6 & 7 & 8 \\
\hline \multirow[t]{2}{*}{ Inter Nodal Length (cm) } & $\mathrm{Y}_{1}$ & 7.31 & 4.00 to 8.90 & 5.20 to 10.37 & 16.19 & 13.93 & 8.25 & 74 & 24.69 \\
\hline & $\mathrm{Y}_{2}$ & 7.35 & 4.40 to 9.30 & 4.70 to 10.50 & 16.93 & 14.89 & 8.05 & 77 & 26.99 \\
\hline \multirow[t]{2}{*}{ Vine length (m) } & $\mathrm{Y}_{1}$ & 4.20 & 2.20 to 6.20 & 2.20 to 6.10 & 28.84 & 27.39 & 9.01 & 90 & 53.61 \\
\hline & $\mathrm{Y}_{2}$ & 4.13 & 1.80 to 6.40 & 2.03 to 6.07 & 29.84 & 28.40 & 9.15 & 91 & 55.69 \\
\hline \multirow{2}{*}{$\begin{array}{c}\text { Number of Primary } \\
\text { Branches per Vine At Last } \\
\text { harvest }\end{array}$} & $\mathrm{Y}_{1}$ & 6.02 & 4.33 to 9.10 & 4.03 to 8.83 & 24.18 & 22.41 & 9.06 & 86 & 42.81 \\
\hline & $\mathrm{Y}_{2}$ & 5.97 & 4.10 to 8.50 & 4.03 to 8.83 & 24.58 & 22.86 & 9.04 & 86 & 43.79 \\
\hline \multirow{2}{*}{$\begin{array}{l}\text { Fruit length }(\mathrm{cm}) \text { of } \\
\text { marketable fruits }\end{array}$} & $\mathrm{Y}_{1}$ & 29.30 & 15.30 to 38.40 & 20.17 to 42.83 & 20.50 & 18.52 & 8.79 & 82 & 34.47 \\
\hline & $\mathrm{Y}_{2}$ & 30.00 & 13.30 to 37.80 & 21.33 to 41.93 & 20.23 & 18.01 & 9.22 & 79 & 33.02 \\
\hline \multirow[t]{2}{*}{ Fruit Diameter (cm) } & $\mathrm{Y}_{1}$ & 2.84 & 2.17 to 4.10 & 2.10 to 3.87 & 17.07 & 14.56 & 8.91 & 73 & 25.59 \\
\hline & $\mathrm{Y}_{2}$ & 2.91 & 2.10 to 3.87 & 2.47 to 3.63 & 13.31 & 9.79 & 9.01 & 54 & 14.85 \\
\hline \multirow[t]{2}{*}{ Number of fruits per plant } & $\mathrm{Y}_{1}$ & 23.54 & 12.33 to 33.60 & 13.30 to 38.37 & 25.59 & 23.86 & 9.24 & 87 & 45.84 \\
\hline & $\mathrm{Y}_{2}$ & 23.40 & 12.30 to 30.50 & 14.43 to 37.07 & 24.34 & 22.65 & 8.91 & 87 & 43.42 \\
\hline \multirow[t]{2}{*}{ Average fruit weight (g) } & $\mathrm{Y}_{1}$ & 167.88 & 96.23 to 220.33 & 112.93 to 242.70 & 20.48 & 18.99 & 7.66 & 86 & 36.27 \\
\hline & $\mathrm{Y}_{2}$ & 161.99 & $\begin{array}{c}108.93 \text { to } \\
205.87\end{array}$ & 104.17 to 247.00 & 21.22 & 19.79 & 7.65 & 87 & 38.03 \\
\hline \multirow{2}{*}{$\begin{array}{c}\text { Marketable fruits yield per } \\
\text { plant (kg) }\end{array}$} & $\mathrm{Y}_{1}$ & 3.40 & 1.64 to 3.76 & 2.29 to 5.01 & 23.1 & 21.83 & 7.81 & 89 & 42.35 \\
\hline & $\mathrm{Y}_{2}$ & 3.28 & 1.62 to 3.64 & 2.15 to 5.17 & 24.73 & 23.49 & 7.75 & 90 & 45.95 \\
\hline
\end{tabular}


Heritability estimate which provides the assessment of transmissible genetic variability to total variability happens to the most important basic factor in determining the genetic improvement and response to selection. The estimates of high heritability (Table 2) was observed for node number to first staminate flower anthesis, node number to first pistillate flower anthesis, number of nodes per per vine at last harvest, vine length (m) at last harvest, number of primary branches per vine at last harvest, fruit length of marketable fruits, marketable fruit yield per plant $(\mathrm{kg})$ and average fruit weight $(\mathrm{g})$, whereas low to moderate magnitude of heritability for remaining traits. The high heritability coupled with high genetic advance was observed for node number to first staminate flower anthesis and vine length at last harvest. The high heritability along with moderate genetic advance observed for node number to first pistillate flower anthesis, number of primary branches per vine at last harvest, number of fruits per plant, average fruit weight and marketable fruit yield per plant. The above mentioned findings are in agreement with earlier reports (Prasuva and Rao, 1988 in cucumber; Indiresh, 1982; Abdul Vahab, 1989; Rajput et al., 1996 and Singh, 2006 in bitter gourd; Bindu et al., 2002 in pumpkin and Hawlader et al., 1999 in bottle gourd, Singh et al., 2002 in ridge gourd).

\section{References}

Abdul Vahab, M. 1989. Homeosttic analysis of components of genetic variance and inheritance of fruit colour, fruit shape and bitterness in bitter gourd
(Momordicacharantia L.); Ph.D. Thesis Deptt. Of Olericulture, K.A.U. Vellanikkara.

Bindu, S., Mhakal, K.G., Kale, P.B., Sakahre, S.B. and Chitra, K.R. 2000. Genetic variability in pumpkin (Cucurbit amoschata Duch ex Poir. Annals of Plant Physiol., 14: 66-68.

Burton, G.W. and deVane. E.W. 1953. Estimating heritability in tall Descue (Festuca arundinaces) from replicated clonal material.

Hawlader, M.S.H., Haque, M.M. and Islam, M.S. 1999. Variability, correlation and path analysis in bottle gourd. Bangladesh $J$. Scientific and Indust. Res., 34(1): 50-54.

Indriesh, B.T. 1982. Studies on genotypic and phenotypic variability in bitter gourd. $J$. Agric. Sci. Bangalore, 8(10): 32

Johnson, H.W., Robinson, H.F. and Comstock, R.E. 1955. Estimation of genetic and environment variability in soybeans. Agron. J., 47: 314-318.

Mohanty, B.K. 2000. Studies on variability and selection parameter in pumpkin. Haryana $J$. Hort. Sci., 30: 86-89.

Panse, V.G. and Shukhatme, P.V. 1984. Statistical methods for agriculture workers $\left(2^{\text {nd }}\right.$ eds.. Indian Council of Agri. Res., New Delhi.

Prasuva, M.N. and Rao, M.R. 1988. Variability studies in cucumber. South Indian Hort., 36(5): 237-341.

Singh, A.K. 2006. Genetic variability and correlation studies for yield and its component traits in bitter gourd (Momordicacharantia L.); M.Sc.(Ag) thesis, Deptt. Of Vegetable Science, N.D.U.A.T, Kumarganj, Faizabad.

Singh, Ranjit, C., Alam, Anis and Singh, Vinod. 2002. Purification characterization and chemical modification studies on a translation inhibitor protein from Luffacylindrica. Ind. J. Biochem. Biography, 40: 31-39.

\section{How to cite this article:}

Praveen Kumar Singh, V.B. Singh, Chandan Kumar Singh, Manoj Kumar, Vimlesh Kumar and Nitish Kumar. 2017. Evaluation of Germplasmfor PCV, GCV and Heritability in Luffa (Luffa cylindrica Roem.). Int.J.Curr.Microbiol.App.Sci. 6(3): 355-360.

doi: https://doi.org/10.20546/ijcmas.2017.603.040 